International Journal on Emerging Mathematics Education (IJEME)

Vol. 1, No. 2, September 2017, pp. 147-168

P-ISSN: 2549-4996, E-ISSN: 2548-5806, DOI: http://dx.doi.org/10.12928/ijeme.v1i2.6647

\title{
Images of Mathematics Held by Undergraduate Students
}

\author{
${ }^{1}$ Basanta Raj Lamichhane, ${ }^{2}$ Shashidhar Belbase \\ ${ }^{1}$ Kathmandu University, Dhulikhel 45200, Nepal \\ 2Zayed University, Academic City, Dubai 19282, United Arab Emirates (UAE) \\ e-mail: mebasanta98@gmail.com
}

\begin{abstract}
Abstrak
Tujuan penelitian ini adalah untuk mengeksplorasi citra matematika dari sudut pandang mahasiswa program sarjana dan faktor-faktor yang mungkin memengaruhinya. Pada penelitian ini, citra matematika dimaknai sebagai pandangan atau representasi mental terhadap matematika, yang dialami oleh mahasiswa program sarjana dalam perjalanan akademiknya melalui interaksi secara luas di sekolah. Penelitian ini menggunakan teori kekerasan simbolis oleh Pierre Bourdieu untuk mengevaluasi citra matematika di mata mahasiswa. Desain penelitian ini adalah eksploratif kualitatif dan interpretatif. Wawancara semi terstruktur digunakan untuk mengumpulkan data teks dari tiga subjek penelitian yang merupakan mahasiswa tingkat akhir program sarjana matematika di Universitas Tribhuvan di Kathmandu. Berdasarkan analisis dan interpretasi tematik dari data tekstual, terdapat empat citra matematika yang muncul dari sudut pandang subjek. Citra-citra tersebut adalah: matematika itu sulit dan abstrak; tidak konteksual; mata pelajaran yang misterius; dan dapat diterapkan di berbagai bidang ilmu. Faktor-faktor penyebab terbentuknya citra tersebut berkaitan dengan pendekatan kurikuler dan pedagogis dari jenjang sekolah hingga perguruan tinggi. Di antaranya adalah metode mengajar yang konvensional dan tidak menguatkan siswa; kurikulum, buku, maupun sumber belajar lainnya yang tidak kontekstual; media pengajaran; serta hakikat matematika itu sendiri.
\end{abstract}

Kata Kunci: citra matematika, hakikat matematika, kekerasan simbolis, pendekatan pedagogis, penelitian kualitatif

\begin{abstract}
The purpose of this paper is to explore images of mathematics held by undergraduate students and possible influencing factors. We conceptualize the image of mathematics in this study as the mental representations or views of mathematics as undergraduate students experienced during their academic journey through the interaction largely at school and university. Pierre Bourdieu's construct of symbolic violence served as the theoretical lens to evaluate the students' images of mathematics. The design of this study was explorative qualitative and interpretive. We used a semistructured interview to generate data texts from three participants who were senior undergraduate students studying mathematics at an affiliated college of Tribhuvan University in Kathmandu, Nepal. From the thematic analysis and interpretation of the textual data, four common themes emerged as images of mathematics held by the participants. These include-- mathematics as a difficult and abstract subject, decontextualized, mysterious, but applicable in different fields. The influencing factors for these images are mainly related to the curricular and pedagogical approaches from schools to university classes. These factors comprise-- conventional and disempowering methods of teaching, decontextualized curriculum and textbooks, other teachinglearning resources, the medium of instruction, and nature of mathematics itself. We address pedagogical implications of the findings and present the conclusion.
\end{abstract}

Keywords: images of mathematics, nature of mathematics, symbolic violence, pedagogical approach, qualitative research

How to Cite: Lamichhane, B.R., \& Belbase, S. (2017). Images of mathematics held by undergraduate students. International Journal on Emerging Mathematics Education, 1(2), 147-168. http://dx.doi.org/10.12928/ijeme.v1i2.6647 


\section{INTRODUCTION}

First, we introduce the context of the study. Second, we discuss the theoretical framework for this study in terms of absolutist and fallibility images of mathematics and symbolic violence as a basis to interpret the images. Third, we outline the method of data collection, analysis, and interpretation. Fourth, we present the major themes and discuss them in relation to the relevant literature. Finally, we address some pedagogical implications followed by the conclusion.

\section{Context of the Study}

In the context of Nepal, mathematics education activities focus on memorizing and reciting of certain mathematical facts, rules, formulae, theorems and solving certain mathematical problems by the routine of algorithms without regarding conceptual and relational understanding for the sake of achieving better grades in final examinations (Panta, 2016). But, the results did not support the claim, and most of the students failed in School Leaving Certificate (SLC) attributed to the failure in mathematics (Mathema \& Bista, 2006). Our educational practices, in general, do not treat and teach students in a holistic approach. The classroom environment rarely appreciates democratic norms and values. That is, students hardly get a chance to share their experiences, raise questions and participate in class discussions with the teacher and other students. Most of the time, one-way communication takes place in the classroom, and consequently, the students do not conceptualize contents, and they do not have an opportunity to relate contents to their daily lives (Luitel, 2009). Similarly, mathematical contents, textbooks, and other instructional materials are highly decontextualized. Therefore, most of the students regard mathematics as a foreign subject and pure body of knowledge (Luitel, 2009). There are other issues, for example, gap between theory and practice in mathematics education, lack of teaching aids and materials, social issues related to gender and language, and cultural issues related to diversity and ethnicity (Panthi \& Belbase, 2017) which ultimately contribute to the different images of mathematics. Therefore, the experience of learning in classrooms in Nepal significantly affects students' images of mathematics. It is imperative to study the images of mathematics held by students to understand what affects their learning.

\section{Brief Review of Literature}

Mathematics has become increasingly important in almost every aspect of our complex technological society. Expertise in mathematical computation, knowledge, skill, and problem-solving techniques are not only necessary for physical and space sciences but also for social sciences and everyday lives. Despite its importance, there is a widespread decreasing trend of students taking mathematics as their future career subject after completing school-level mathematics education. Mann (2005) reported that less than $1 \%$ of the US students who enrolled in university level selected mathematics as a major field of study and their interest in mathematics gradually evaporated as they enter in higher education. Comparing to the early stage of mathematics education, students show negative attitude and belief towards mathematics in the later years of schooling and tertiary level (Parveva et al., 2011). The US Department of Education (2003, as cited in Mann, 2005) found that there was an unexpected change in attitude towards mathematics among fourth and eighthgrade students. This study also revealed that only $35 \%$ of the eighth-grade students had positive attitude whereas $85 \%$ of the fourth-grade students had that attitude toward mathematics. Such attitude towards mathematics might be harmful and help in formulating the negative image and myth of mathematics. It indicates that there is a

IJEME, Vol. 1, No. 2, September 2017, 147-168 
substantial evidence of lack of interest in mathematics and consequently increase the avoidance of mathematics during their academic and professional career (Preston, 1986). Why such conditions arise in mathematics education? How do these images of mathematics emerge? What are the forces behind it? How to resolve it? These are some of the striking questions that created some tensions and confusions to us. In this regard, we were highly enthusiastic to explore how the students perceive different images of mathematics.

Furthermore, many researchers (e.g., Beswick, 2007; Kloosterman, 2003; Marshman \& Grootenboer, 2012) argued that to enhance the quality of mathematics education, teachers and students' beliefs, attitudes, dispositions, and emotions should have taken into consideration that might help to germinate the different images of mathematics during their educational journey. Because of lack of student-friendly pedagogical practices, acceptance of one-dimensional nature of mathematics, myths of mathematics in society and primarily focuses on isolated utilitarian values of mathematics, most of the students regard mathematics as difficult, cold, abstract, theoretical, ultra-rational, important, and largely masculine (Ernest, 2008). In our understanding, every people have their views regarding mathematics and its applicability. Through the socio-cultural interactions, mathematics teachers and students bring their differentiated views in their classroom.

In our traditional classroom teaching-learning activities, we can rarely imagine the ideal speech situation (Taylor \& Williams, 1992) in which every student can share their lived experiences and thus enrich their experiences. In a traditional hierarchical system, teacher voices and their approaches are regarded as authentic and pure, and all others' experiences are doomed. As we witnessed as the students, teachers and teacher educators, these experiences not only hinder the mathematics education but also flourish the grounds for negativity that might have an ever-lasting impact on academic and professional lives of practitioners. In this connection, we realized that exploring mathematical experiences from the participants' perspectives creates a new discourse in our context (in Nepal) in which most of the research practices are governed by the post/positivist paradigms. In these perspectives, most of the educational research results and findings have been expressed in a functional relationship mainly isolated from participants' voices, perspectives, and experiences. Such instrumentalist and mechanistic approaches might flourish the grounds of onedimensional views regarding mathematics as certain, incorrigible, unique, and valuefree. These views certainly have that impeded contextualization of mathematics education practices. In this connection, we claim that this study can be beneficial for the readers (largely teachers, administrators and researchers), as it explores the images of mathematics from the participants' perspectives through humanistic, contextualized, and emerging approaches. It also might help in revisiting the readers' and mathematics education practitioners' experiences through a self-reflexive method that assists for the betterment of future mathematics education.

In this study, we would like to uncover the images of mathematics held by under graduate students. We consider the images of mathematics as mental schema based on the views or conceptions emerged through lived experiences of individuals. We acknowledge Sam's (1999) definition of the image of mathematics as "mental representation of something which is directly associated with conceptions, attitudes, and beliefs that are germinated through the social interactions and past experiences" (p. 72). It incorporates mainly two aspects of learning mathematics-- affective and cognitive. Affective domain refers attitude, feeling, and emotions whereas cognitive 
domain reflects knowledge and belief. The images of mathematics not only germinate through the social interaction but also from a nature of mathematics (philosophy) and its values. Incorporating this aspect, Belbase (2013) argues that there are generally three roots of germinating the images of mathematics: epistemological, philosophical and pedagogical. It indicates that images of mathematics held by practitioners do not have a single root as compared to the other affective and cognitive components. Mathematical beliefs and perceptions towards mathematics fundamentally depend on the individual mental reaction to a particular event and remain highly fluid that is easily liable to change. Their reflective and reflexive beliefs (Belbase, 2016) about the subject matter due to long held conceptions and experiences affect students' image of mathematics either as given to them or constructed by them with the help of teachers. As a result, the images so formed may influence their attitudinal and cognitive beliefs about the nature of mathematics and learning mathematics (Belbase, 2017). Therefore, images of mathematics are interwoven with many other affective, cognitive, socio-cultural, socio-political, philosophical, and pedagogical components. After the formation of certain images of mathematics, it is very difficult to change, and it may affect in mathematics teaching-learning activities.

Different studies show that images of mathematics held by students influence their future interest to study the subject (Osman, $\mathrm{Pa}, \&$ Othman, 2010). Positive images may help in forming positive beliefs, and negative images may assist in forming negative beliefs toward mathematics that shape the students' interest, attitude, value, and motivation to pursue mathematics or mathematics related subjects for study and future career (Belbase, 2015; FitzSimons, 2002). Also, the images of mathematics formed by students may have a robust relationship to the images of teachers they hold based on their classroom experiences (Palmer, 2015). These classroom experiences are affected by teachers' pedagogical or instructional practices that are influenced by their images of mathematics (Mura, 1995; Sterenberg, 2008).

In this regard, we believe that image of mathematics is nothing but a product of mathematics practices largely based on pedagogical, philosophical, curricular, sociopolitical, cultural and personal experience within and outside of school. Based on these practices and activities, something happens to the practitioners' mind that may influence on one's personality and disposition to mathematics, and such individually granted disposition to mathematics is considered as an image of mathematics in this study. The study of this kind is significant in the sense that the images held by students about mathematics and the potential sources of such images can be helpful in designing lessons, curricular materials, and assessments (Martin \& Gourley-Delaney, 2014). The images students form about mathematics in the classroom may influence their thinking, learning, and that may also influence their future classroom practices (Palmer \& Karlsson, 2017).

\section{Purpose and Research Question}

The main purpose of this study is to explore the images of mathematics held by undergraduate students during their educational journey, and their prevailing forces behind these images. The research questions of the study are: What images do undergraduate students have about mathematics? Why do they have such images of mathematics? To explore the research questions, we reviewed different viewpoints and images of mathematics emerged throughout its history. Mathematics has been regarded as one of the most important tools for the early age of counting to the modern age of modeling and describing the real-world phenomenon more consistently and a subject of enhancing the ecological consciousness in the post-modern era. To

IJEME, Vol. 1, No. 2, September 2017, 147-168 
provide a glimpse throughout its history that helps us to organize and interpret our textual data, we would like to discuss the theoretical framework of the study in the next section.

\section{THEORETICAL FRAMEWORK}

In the history of mathematics, there were different views of mathematics. Mathematics has a significant role in the development of human civilization throughout the world and seeing mathematics as socio-cultural and historical entities makes it obvious that it's taught and learned (Hersh, 1997). Gradually, when formal education systems started then it was confined to schools. Because of its utilitarian values and consistent power to describe the immediate environment related to everyday human lives, people started perceiving mathematics differently and then diverse images of mathematics emerged which can be broadly categorized into two domains-- absolutist and fallibility images (Ernest, 1991 \& 2008).

\section{Absolutist Image}

Hersh (1997) highlights some deeply rooted myths about the mathematics as unity, universality, certainty, and objectivity. That is, the mathematical truth is the same for everyone, no matter who invented it. Mathematical proofs and methods are rigorous which yield absolute and universally generalizable conclusions without regard to time, place, and culture. Thus, mathematical knowledge is independent of or prior to human consciousness and tenable with belief in 'Divine Mine' (Hersh, 1997) and so it pushes beyond the reach of general people. Similarly, Lerman (1990) presents the absolutist images of mathematics as a certain, absolute, value-free, abstract and indubitable body of knowledge that follows rigid algorithm discovered by great mathematicians. This image of mathematics has been transferred from teacher to students and hence to the society. Personal views and perceptions of mathematics implicitly and explicitly affect the teaching and learning activities because all mathematical pedagogy rests on a philosophy of mathematics (Lerman, 1990). Similarly, absolutist views of mathematics regard mathematics as the value-free, cultural-free and uncontaminated from human activities enforced to adopt the instrumentalist pedagogical practices. Instrumentalist pedagogical practices focus on the reproduction of same mathematical facts and formulae so that students passively store these facts into their mental store supposed to be useful for future.

Such robotic style of teaching-learning mathematics has adverse effects on students and helps to germinate negative images of mathematics as theoretical, ultrarational, remote and inaccessible to all, but a few extra ordinary human beings with 'mathematical minds' (Ernest, 2012). These negative images of mathematics are also related to anxiety and failure in mathematics. Math anxious individuals who cannot gain competence or mastery of mathematical operations, have little confidence in their ability which directly influences their performance and it severely limits their mathematical activities (Pradeep, 2006; Preston, 1986; Probert, 1983) and thus creating negative images of mathematics (Belbase, 2013).

\section{Fallibility Image}

Another philosophical view of mathematics is fallibilism. Fallibility thought of mathematics argues against the absolutist view. In this view, mathematical objects are considered as an invention of human discourse during their historical and sociocultural practices (Ernest, 1998). That is mathematical knowledge is the product of human activities because human beings live in a community, work together, share their ideas, values, norms and construct their knowledge accordingly for the 
betterment of their lives. Therefore, mathematical knowledge is not certain, not absolute, not universal and does not lay on a single foundation, but it is more contextual, value-laden, cultural and always open to revision (Ernest, 1998). Under this assumption, mathematical knowledge has been created by an inductive process in which experimental procedures play a vital role and recognize the humanizing pedagogical approach. It applies social constructivist approaches to teaching-learning activities in which students are truly engaged in mathematical activities for enriching their conceptual and relational understanding (Belbase, 2014). Moreover, Ernest (2012) argues that fallibilist view of mathematics incorporates the humanistic values of mathematics that further gives rise to the humanistic image of school mathematics. Thus, the image of mathematics held by an individual is a social construct through the actions and interactions during his or her academic, professional, and personal journey. However, the available pieces of literature and the first author's own experiences as a student, teacher, and educator, the contemporary teaching-learning activities have not incorporated the humanistic pedagogical approaches.

The review of the broad philosophical construct helps us in conceptualizing our study with concepts of images of mathematics and the inherent forces that implicitly or explicitly contribute to the formation of such images. It also helps us in recognizing the different aspects or factors that are grounded in the real-world situations that we should consider during the field visit. Moreover, it provides general and tentative components or factors that we should take into account during the semi-structured interviews, formal and informal communications so that we (researchers) can easily grasp the images of mathematics held by the participants. For example, Hersh's (1997) suggests 'front and back' metaphors of mathematics that illuminates where should one pay attention and where one needs to immerse within their activities from which he or she can generate a rich textual information that is more viable for the formation of images of mathematics.

As we already discussed, most of the pedagogical activities in our school have been guided/dominated by behaviorist school of thought in which the teachers deposit his/her knowledge within empty minds of passive learners (Freire, 1973 as cited in Mason, 2010). The classroom seems to be more autocratic and technocratic in which one-way communication dominates students' voices. Such classroom situations and institutional activities indirectly ignore students' identities and thus disempower them, which is one form of violence, what Bourdieu (1991) called symbolic violence served as our theoretical referent. Also, the absolutist image of mathematics comes from the positivistic notion of mathematics and the fallible image of mathematics comes from the poststructuralist notion of mathematics. These two images largely shape one's views, perceptions, beliefs, and attitudes toward mathematics which have not been widely discussed in the past empirical studies although there are theoretical constructs discussed in the literature (Belbase, 2013). Hence, we used these two images as a frame of reference or conceptual referents to identify and discuss images of mathematics formed by the research participants that further relates to Bourdieu's (1995) symbolic violence.

\section{Symbolic Violence}

Symbolic violence occurs in a classroom situation according to the degree whether the classroom environment is learner friendly or teacher used symbolic power as the taken for granted arbitrary power (Bourdieu, 1995). Within classroom teaching learning activities symbolic violence is nothing but any action or behavior taken by the teachers and so-called intellectually brilliant and mainstream students

IJEME, Vol. 1, No. 2, September 2017, 147-168 
that affect the comparatively low achievers or slow learners and minority groups. According to Grenfeel and James (1998), all forms of an instructional approach based on transmissions of values, norms and cultural aspects of so- called elite groups provided the grounds for symbolic violence. Our educational institutions were taught by preconceived values, norms, and beliefs so that they indirectly involved in reproducing the dominant culture of ministering groups. Similarly, the power centric hierarchy classroom management and teaching-learning activities impose artificially constructed objectified abstract knowledge without due consideration of conceptual and relational understanding. Such practice creates havoc among the students, and it also is another form of symbolic violence.

Symbolic violence also appears in a classroom in terms of the language of teaching and learning in almost every educational institution. In this connection, Bourdieu and Passeron (1990) argue that all pedagogical actions, that have been taken place in our traditional school system suffer from some sort of symbolic violence as it is the imposition of cultural arbitrary by an arbitrary power. Furthermore, Bourdieu (1995) signify that an educational institution that is more consistent, uniformly structured and follows materialist approach lays the foundation for the theory of symbolic power within certain cultural milieu. Hence, symbolic violence may deeply affect mathematics teaching and learning and images formed by the students to the subject matter.

Mathematics itself is the product of cultural activities, but classroom practice is just opposite to it. Mathematical knowledge is created by socio-cultural activities of different social and professional groups. Mathematics classroom teaching and learning activity is one form of cultural activities within and outside the educational institution. Symbolic violence may also occur in the mathematics classroom in which there is a lack of understanding of each other's style of communication, learning abilities, and cultural values. Such classroom environment helps students to formulate negative images of mathematics during their academic journey, as they cannot unlock the meaning of the mathematical concepts. Hence, images of mathematics formed by students largely depend on the teaching and learning of mathematics which are influenced by teachers' "personal epistemology, epistemic positions, epistemic cognition, epistemic beliefs, epistemological worldviews, and epistemological understanding" (Rolka \& Roesken-Winter, 2015, p. 75).

\section{RESEARCH METHOD}

This study focused on exploring the images of mathematics held by undergraduate students and their constituent factors. In doing so, we deployed the qualitative narrative research design because it helped us to capture the experiences of participants from their perspectives (Creswell, 2012). For this, we need information-rich participants (Patton, 2002), so that they can supply adequate information. Similarly, Morse (1994) argued that in qualitative research, a researcher can choose his or her research participants so that they have the necessary knowledge, information and experiences of the issues being investigated and easily accessible (as cited in Cohen, Marion, \& Morrison, 2007). Keeping this view in mind, the first author decided to choose one of the colleges of Kathmandu valley, Janata Public College (pseudonym) as the research site. We realized that explorative qualitative research demands more time and multiple ways of generating textual information from the research fields. According to Creswell (2012), to capture the essences of participants' experiences and ensure the standard of qualitative research, a small sample is more 
appropriate than that of a large sample. Keeping this view in mind, we selected only three students (two men and one woman) purposively (Patton, 2002) as the research participants based on convenience and their interest to volunteer in the study.

These three participants were selected purposefully from the Faculty of Education at Tribhuvan University, majoring mathematics education in an Urban College in Kathmandu. They got their school education from the rural area of Nepal in which schools always face a problem of inadequate infrastructures, human resources, and other teaching-learning resources. The participants revealed that there was always a lack of mathematics and science teachers. School of rural areas of Nepal became a place of experimentation for the novice teachers. Every teacher came to schools for rarely 6 to 7 months and shifted the urban areas for their professional and academic enhancement after gaining some experiences. Such educational environment has both positive and negative effects on their educational journey. This severe condition of inadequate human resources gave them an insight into becoming good mathematics teachers. For the participants, mathematics is a subject of social prestige that can deserve the highly payable market opportunities. It is one of the most important factors that they retain mathematics education as their future career subject. Instead of having such positive impact, they shared a lot of negative experiences of being a rural student in Nepal in which teaching-learning activities largely focused on the important questions that had a chance to appear in so-called standardized final examinations. To pass the final exam, they took tuition classes before and during the examination periods by going nearby cities where the private tutors were easily available. All of them have a previous average achievement in mathematics in their schools to early university education. It indicates that from the very beginning of school to the university level these students had vivid experiences of learning mathematics. Therefore, the first author purposively selected these participants for this study that seem to be more representative of undergraduate students who could provide their wider, intense, and illuminative experiences that helped us to explore the images of mathematics from their perspectives.

After selecting the research participants, the textual data were generated by using open-ended interviews, informal communication and their stories about the mathematical experiences during their educational journey. The field texts, information, and stories were generated in three stages. In the first visit, the first author took the participants' consent and clarified the objectives of the research. Then he talked to them about the mathematics education practices in Nepalese context that helped us to understand their mathematical experiences. In the second visit, he deeply engaged them in-depth interviews and informal communication to learn about their mathematical experiences and how they created the image of mathematics. It provided us a lot of information about their experiences. Finally, he heartily requested them to write their mathematical experiences that they gained during their educational journey. Before visiting the third time, he transcribed the previous interviews, field notes and made an explicit understanding about their experiences. Therefore, during the third visit, he discussed with them some concepts that remain unclear and collected their written stories about their mathematics education. These written documents, interview transcripts and field notes of informal communication were used for further thematic analysis and interpretation.

For the processing and analyzing the textual data, we adopted the procedures of the combination of descriptions, analysis, and interpretation to generate the meaning of the textual data (Wolcott 1994 as cited in Creswell, 2007). Considering 
interpretation as a meaning making process, we critically tried to capture the factors and components that gave some discomfort, mental tensions, problems of language, imposition of arbitrary power to the learners, ignored voice of the learners, acknowledge the certain cultural disposition, and disparities among cultural and economically backward students that were some of the features of symbolic violence (Bourdieu \& Passeron, 1990) that contributed to the formation of different images of mathematics. The notion of symbolic violence relates to how the one-way-border crossing (Giroux, 1992) of mathematics knowledge became a source of degenerative images under the cover of formalistic and positivistic notions of hard control and cold reasons (Taylor, 1996) of formulaic approach to mathematics education in Nepal. In doing so, the first author read and reread the stories, informal communication notes and interview transcripts several times to generate related categories. He brought the similar (related) categories in one group for generating themes. Based on these themes, we explored the images of mathematics from their perspective and influencing factors for formulating different images of mathematics. Our interpretation of images of mathematics held by the participants is based on Sam's (1999) frame that includes - attitudes, beliefs, mathematical myths, conceptions, and emotions. This framework helped us to categorize whether an image formed by the research participant is aligned to inherent absolutist or fallibilist philosophy that consequently formed the absolute/fallible images (Ernest, 1991).

\section{RESULTS AND DISCUSSION}

The main objective of the study was to explore the images of mathematics held by undergraduate students of mathematics education. For this, the first author collected the personal experiences of mathematics through their narratives about their educational journey, interview, and informal communication, stories. After collecting these anecdotes, interviews, and stories, he read and reread them until and unless he could capture the essences of their experiences in mathematics in related themes.

\section{Images of Mathematics Held by the Participants}

From this process of making meaning of the textual data, four themes about their images of mathematics emerged from the data. These themes were-mathematics is difficult and abstract, decontextualized, mysterious, and applies to real life practices.

It seems to be cultural exposition in our context in Nepal that math and science are difficult subjects in schools and higher levels. With akin to this popular view, one of our participants, Sulav (pseudonym) expressed his views, "I had learned different subjects in school but mathematics was found very difficult and abstract." Similarly, another participant Saurav stated that "....... signs and symbols were newer and abstract; it made me difficult to learn mathematics." Both participants' views signified that they felt mathematics difficult to learn because of its abstruse symbols. Similarly, Sarita, another participant, expressed her experiences as:

Mathematics is a collection of unchanged definitions, postulates, and theorems. Teaching mathematics means reproduction of these theorems in a meaningless manner and my work is to recite these concepts as needed.

The participants' views indicated that they felt mathematics difficult in three ways. First, they compared mathematics with other subjects. They found other subjects more relevant than mathematics as akin to Luitel and Taylor (2005) examined mathematics in other school subjects and found no story in mathematics, and thus had made an image of mathematics as a foreign subject. As Sulav mentioned 
that mathematics was found to be less relevant as compared to other subjects, immediately the first author asked him to clarify his statement. After pausing some time, he compared mathematics and social study classes. "In our social study class, the teacher always gives more examples, which we encounter in our daily lives and tells the brave history in which our ancestors win over the enemies. We do not want to miss social study class but hardly want to present in the mathematics class in which no familiar examples and stories are discussed. It makes me more irritated and I stay in a class only to escape corporal punishment by the teacher."

The participant (Sulav) compared mathematics class with social study class during his school life. He articulated how social study class generated more interest to be in the class and hear more about the heroic actions of the ancestors whereas, the mathematics class seemed to be full of symbols and languages of mathematics instructions that were largely unfamiliar to them. Sarita, a participant from the minorities group, ventilated her experiences that she had difficulty in understanding the geometrical names, figures, their properties, and theorems that were quite different from their cultural practices. She was in a tension how to pass the school leaving certificate (SLC) examination in mathematics as she dropped all questions from the geometrical parts in her earlier grades. The symbolic expressions of mathematics made it more abstract to them.

Third, teachers used conventional method of teaching in which they were likely to reproduce the same mathematical contents repeatedly, that Bourdieu (1991) called cultural reproduction, a form of symbolic violence in schools which suppressed the students from minorities because the schools adopted the elite culture as a norm and urged these minority children to accept imposed culture as legitimate and authentic knowledge by using arbitrary power. Moreover "this problem can be understood from a socio-cultural perspective that draws a direct connection between cognition and culture" (Kathmandu University \& UNESCO Kathmandu Office, 2008, p. 9). The formal mathematics in school mostly does not recognize the local practices as an authentic source of teaching-learning mathematics. Abstruse symbols, transmissions' approaches of teaching learning activities, and absolutist views of mathematics lead to abstraction and raising the difficulty to the students in making sense of their mathematics learning. From this discourse, we realized that mathematics students, in general, have a mental pressure to cope with the problem solving and dealing with structured step-by-step processes that they cannot explicitly express are forms of the symbolic violence.

In our context (in Nepal), Mathematics textbooks are the primary sources of teaching learning activities for teachers and students. Almost all the textbooks follow Anglo-Indian traditions (Luitel, 2009) in which very rare examples and exercises are related to our cultural contexts, and their languages and symbols are quite different from daily practices. The research participants have shared similar experiences. For example, Sarita expressed her views:

Mathematical pedagogical practices in my classroom are obscure, most of us cannot understand their context, where, when and how we can use it. What is the significance of such mathematical practices in our socio-cultural context?

These views of participants indicated that their images of mathematics are decontextualized based upon the pedagogical practices, utility, and relevance of learned mathematics concepts in our day-to-day life. As students are not able to relate their mathematical knowledge, they feel that it is only for intellectual discourse detached from human values and cultures. Most of the textbooks carry foreign flavor

IJEME, Vol. 1, No. 2, September 2017, 147-168 
that leads mathematical learning distanced from students' home and community practice. Students sought to use his or her knowledge in their immediate environment and their lives. If they were not able to use this mathematical knowledge, they felt disempowered and did not take mathematics they learned as authentic knowledge (Tutak, Bondy \& Adams, 2011). Moreover, such pure, value-free, and decontextualized mathematical knowledge and concepts are only for academic discourse and it is a business of so-called mathematically intelligent persons. Such disempowering notion of mathematics creates havoc in learner's mind that might hinder their mathematical learning ability can serve as symbolic violence. The mathematics curriculum and classroom practices in Nepal mostly guided by rote memorization of rules and algorithms that have contributed to the underachievement in examinations (Kathmandu University and UNESCO Office in Kathmandu, 2008). A study by Mathema and Bista (2006) discussed students' performance in School Leaving Certificate (SLC) examination in Nepal. This study found that many students failed in mathematics on the largest scale compared to other disciplines in schools. The problem of many students failing in mathematics lead to create a poor image of mathematics in schools in Nepal that might have further perpetuated in the higher education too. It indicates that the absolute images of mathematics as decontextualized subject matter prepared the backgrounds for fostering the symbolic violence in a mathematics classroom.

When learners were not able to capture the essence of the mathematics and teachers were not able to crack the meaning of mathematics as per the needs of students, aspirations and social context of learners, then it always remained covert. Consequently, students and practitioners considered mathematics 'out there' subject and beyond the reach of the learners (Ernest, 1991). A participant, Saurav, on his reflective writing, also shared this kind of experience. He expressed in his story:

There were no provisions for project work, academic discussion, use of instructional materials, and almost all time was focused on the mathematical solution of undue problems posed by textbook writers, such dry and cut subject-matters and pedagogical practices gives me an impression of mathematics as mysterious and teachers' subject.

Arguing similarly, Sarita expressed her experiences:

Most of the symbols, technical terms, postulates, languages used in the mathematics class remain unclear and with the help of these symbols, axioms, postulates, the proven theorem become mysterious how and why this happened.

From the views of participants, the mathematics became mysterious subject to them because of the mathematical symbols and sacred pedagogical approach rampant almost all levels of mathematics. The sacred pedagogy and aim of teaching both deeply rooted in Nepalese mathematics education practices are justified by Luitel and Taylor (2007) as "Nepalese mathematics education is ripe for transformation, harboring as it does a view of nature of mathematics as a sacred and fixed body of decontextualized knowledge" (p. 627). Mathematics teaching-learning activities in our schools and universities have been inexplicable as a no discursive body of knowledge that is always mysterious to learners. Similarly, the sacred pedagogical practices rely on the instrumentalist/mechanical understanding of the subject matters that pushed the learners to take a rote memorization as one of the ways to become more familiar with the mathematical facts and theorems. The traditional teaching -learning mathematics excessively focusses on the formal understanding of rules, formulas, and procedures and abstract problem solving (Belbase, 2006). Without conceptual and relational or cultural understanding of the subject matters, no one can grasp the true essences of 
the mathematics and thus remains mysterious forever. Whenever mathematics teaching-learning activities remained mysterious and the students continued pondering for searching a common rule and procedure that trapped the students in the mesh of instrumentalist absolutist thinking and thus preventing the creative, imaginative and critical thinking. Instated of boosting the critical, creative and imaginative thinking that are the basic components of the conscious citizen, schools reproduce same mathematical concepts, procedures, and theorems so what we called a symptom of a form of symbolic violence.

Instead of having negative images of mathematics, almost all participants accepted mathematics is an applicable tool in our daily and professional lives. To give the supportive views most of the participants expressed that they were in the field of mathematics because it is somehow prestigious subject, and it flourishes the opportunity of employment in the job market. For example, Saurav argued:

Frequent scarcities of mathematics teachers, somehow even forced me to regard mathematics learning as job getting activities. I also had a kind of impression that mathematics is a prestigious subject and those students who are good at mathematics are thought to be more intelligent or talented people.

A similar view was put forward by another participant Sulav, "I am learning something, whether, in school or university, that should be useful for my practical life but, mathematics was very abstract."

These views of participants indicated that they were somehow aware of the use of mathematics and power and use of mathematics in society. However, their points of view were restricted only for securing future jobs for their individual life. They regarded mathematics as a tool box having facts, rules, skills, concepts, and knowledge that can be used by trained mechanists (Howse, 2006) for the pursuance of some external end. Moreover, they perceived mathematics as an applicable and important subject as it has a consistent power to describe the real-world problems and gives an absolute, precise, unique and reliable solution to a problem. Most of the practitioners valued mathematics as one of the important subjects for being consistent power to module natural phenomenon in more exactly and accurately (Goodwin et al., 2014). It indicates that absolutist view of mathematics not only gives the negative impression to the practitioners but also provides the grounds for practitioners to appreciate the values of mathematics in their lives and real world situations. From the above discussion, we realized that the research participants have some sort of alternative empowering images of mathematics, but that would not able to germinate as most of the teaching-learning activities distorted the meaning and essence of mathematics for the name of providing the standard and pure mathematical knowledge and concepts. In this regard, we realized that most of the practitioners' absolutist, inflexible, and incorrigible images emerged through the symbolic violence encountered in mathematics education practices.

In our opinion, exploring the images of mathematics alone did not worthy as it only floated and reflected the personal views and experiences of the mathematics but to dig out the possible reasons or factors that help to germinate these images is more significant that may help in improving the teaching-learning activities by addressing these factors. Therefore, our attention has been drawn to explore the forces beyond the formation of above-mentioned images of mathematics. Now, we would like to discuss them in the following sub-section.

\section{Factors on Images of Mathematics}

Images of mathematics held by practitioners constitute largely through their experiences and interactions with immediate environments. As the participants

IJEME, Vol. 1, No. 2, September 2017, 147-168 
expressed their experiences during the interview, formal and informal communication, and their narratives we broadly captured the three factors pedagogical approaches, decontextualized curriculum and textbooks, and perceived nature of mathematics behind the formation of aforementioned images of mathematics.

\section{Traditional Pedagogy}

Most of the images of mathematics held by the participants emerged through transmissionist and didactic pedagogical approaches. These views were supported by the following arguments made by Sarit:

'I couldn't adjust to the school culture because of teachers' language and behavior. I didn't understand the Nepali language which was used in the classroom. Until and unless I completed higher secondary level our teaching learning activities based on traditional teaching style where my position was an inferior receiver of mathematical knowledge rather than co-learner or co-constructer'.

Similarly, Saurav remembered his teaching-learning activities as 'my teacher always teaches us how to recite different algorithms and ways to reproduce them. In university and higher secondary levels, language used in the mathematics teachingteaching activities was very difficult to understand and did not able to grasp the meaning and conceptual understanding of the subject matters. Teachers hardly used the contemporary communication and technological tools and others instructional materials. Most of the times devoted to copying the lecture note on white boards. We as the students hurriedly copied and practiced many times to remember for upcoming final examinations'.

From these arguments, we understood that teaching-learning activities were largely dominated by transmissionist and 'one size fit all' (Freire, 1973 as cited in Mason, 2010) approaches, where the teacher deposited his or her knowledge into passive minds of students. Mathematics classroom seems to be a site of oppression where the students do not get the opportunities to share their views. They are urged to receive passively the same mathematical concepts, knowledge, facts, and theorems reproduced by teachers. Students' voices are silently ignored, as the name of providing the universal knowledge, skills, and concepts are one form of violence in the eyes of Bourdieu (1991) that has been largely dominant in mathematics classroom practices.

Another aspect of emerging such images of mathematics is a language of instructions. Most of the classroom languages of instruction are Nepali only [or English only] in which the students from other cultural and lingual background are suppressed (Awasthi, 2004). Despite this context, the arguments articulated by the participants signified that mathematical language used in the mathematics classroom was declarative. The declarative language is in the form of if then-ism and has a singular meaning and interpretation without regards to time, place, and immediate environment (Luitel, 2009). It indicates that not only the students from the minorities, ethnic and socio-economically backward groups but also the students from the mainstreaming and elites group suffered from the declarative and abstruse languages used in the mathematics classroom. These traditional mathematical practices explicitly and implicitly related to the teacher images or views of mathematics. Teachers hold the absolute images of mathematics regarded mathematics as unquestionable truth having a rigid set of rules and procedures oriented to adopt the traditional pedagogical approaches (Lamichhane, 2016). Moreover, our traditional pedagogical practices become another powerful divider, in which cultural capital (Bourdieu \& Passeron, 1990) of the elite groups in a school/classroom or community 
represents the norms or values that should be adopted by all students. That is, the students from the non-mainstreaming groups doubly suffered from the abstruse symbols and mathematical languages and culturally dominated classroom environments. Such adverse classroom situations may devastate students' own cultures and identities (Mason \& Evers, 2010), other symptoms of symbolic violence resulting in negative images of mathematics.

\section{Decontextualized Curricula and Textbooks}

During the interviews, informal communications and their written narrative, the first author found that the research participants expressed their disapproval feeling or experiences of our curriculum and textbooks. Sarita mentioned that:

Our mathematics teacher always repeated the same sentences when he entered in a classroom. They told that if you delayed in doing your exercise and disturbed me by asking unnecessary questions, I was not able to complete the course or exercises that were more harmful. So, we should complete the course in time that helps to secure the highest marks in our final examination. So please follow my instruction and try to familiarize with these problems or examples by repeating these more and more time. At that time, I thought that why such undue textbooks and problems were encumbered to us. Who designed the course and curriculum that rarely match in our daily lives and practices? Sometimes, it made me confused, why is necessary to read such burden subject. In my opinion, if mathematic is linked with our cultural and social activities that can be understood or taught by playing a game, saying story and dramas it becomes more interesting like Nepali, social study, and history. I don't know, whether there were such tools or techniques in mathematics.

Similarly, Saurav argued that in the similar vein:

I do not understand till today, why I should complete such huge textbook that compiles long and complicated examples and exercises give me more burden. I had no time for other subjects as I had to devote all time to finish my mathematics homework. Moreover, all most all problems were quite unfamiliar to me and were solved by following the same procedures or step by step algorithm given by the teacher. Were there any sources or contexts in our culture or societies in which mathematical problems had emerged so that we could learn easily? Who designed our course or curriculum and made more esoteric? In my experiences, as compared to school grades, university level curriculum and textbooks are quite strange and seem to be inapplicable in real life situations. Actually, I do not grasp the true meaning, essences, and application of derivatives, integrations, differential equations and abstract algebra in which we are compelled to prove long and cryptic theorems. But I can solve the most of the problems posed in our textbooks.

From these expressions of the participants, it seems that mathematical contents are unfamiliar to our own cultural and social practices. That is, our mathematics textbooks are full of undue examples and exercises that disempower the learners rather than encourage or motivate them to learn. It signified that our mathematics education practices do not incorporate the local cosmological knowledge system (Luitel, 2009) for the name of providing the modern scientific mathematical knowledge. When students are not able to triangulate the learning mathematical facts in their socio-cultural milieu and daily lives then they do not appreciate mathematics as their subjects (Kathmandu University \& UNESCO Office in Kathmandu, 2008). It provokes a disempowering image of mathematics so what Luitel and Taylor (2005) expressed the images of mathematics as a foreign subject. Similarly, the curriculum design and revision process largely focus on developing pure mathematical contents

IJEME, Vol. 1, No. 2, September 2017, 147-168 
and unable to maintain a rational balance between applied and pure mathematical contents. Students do not understand the conceptual and relational meaning of the most useful and important concepts or contents of mathematics, for example; derivative, integration, algebra and differential equations. From the very beginning of the school to the university level, the mathematics curricula in Nepal are overloaded by contents. For examples, the mathematics curriculum for primary level in Nepal includes nine different content strands whereas most of the countries who stood in the top position in TIMSS 2015 and PISA 2015 include three to five different content strands largely focused on communicative, reasoning, creating, and problem-solving skills (Lamichhane, 2017). Such mathematics curricular practices somehow are related to the absolute views of mathematics in which emphasis is given to onedimensional Platonic worldviews where mathematics is regarded as independent of human activities, times and context that flourish the grounds for germinating disempowering images of mathematics. Moreover, double-sword weapons victimize our students as it incorporates the western one-dimensional views of mathematics and overloaded contents. Such decontextualized textbooks, centralized curriculum designs or revisions and practices gave the negative perceptions and beliefs towards mathematics contributing to the negative images of mathematics (Sam, 1999).

\section{Perceived Nature of Mathematics}

Nature of mathematics was regarded as another influencing factor to formulate the images of mathematics. Most of the participants expressed their views that in their primary and early secondary levels they were more enthusiastic to learn mathematics, but gradually it turned to be disempowering subject and bemused them if they could continue their study or not. Saurav presented his view as:

During my secondary level, mathematics was one of my favorite subjects and I was always ready for mathematics. When I entered to the university level and continued my study in the field of mathematics education. I found mathematics as a boring subject because of its abstruse language and unfamiliar symbols, only associated with the classical theorems.

Similarly, in responses to a question "How did you perceive mathematics during your school and university years?", Sarita replied that "mathematics is a subject which deals with the universal truth, certainty and unchallengeable knowledge. Sometimes, our university teachers tried to encourage us by highlighting the nature of mathematics as one of the scientific subjects provided a firm foundation of all other human disciplines. So, the students from the different parts of the world read and learn essentially the same mathematical contents without regards to time and context."

These views expressed by participants indicated that they have deep rooted images of mathematics as the absolute subject emerged through their classroom activities. In early grades of mathematics, some arithmetical and geometrical problems have some real-life connection. Gradually, the curricula and textbooks focus on more rigorous mathematical problems which the students cannot connect their classroom mathematics with their real-life situations. It further helps to germinate absolutist images of mathematics among the practitioners. Moreover, our textbooks and other learning materials intensely depend on Eurocentric western thoughts and they lack relevancy in our cultural context so what Luitel (2009) called decontextualized mathematics. Another claim was that conventional pedagogical practices largely devoted to mathematical algorithms for the sake of a single answer. Purely didactic account of mathematical activities suppressed the dialogical nature of mathematics 
(Ernest, 1994) in which almost all students vividly looked mathematics as pure, certain, and context and value-free.

Arguing in the same line another participant, Sulav expressed:

As a university student, I tried to associate some concepts to my day to day life but most of the concepts; I could not find any relation to my everyday life due to their symbols and didactic formulation, which could sometimes make me disappointed.

These arguments indicated that most of the university level mathematics as compared to school level is difficult, rigorous and guided by nominalism, symbolism, and Platonism (Howse, 2006), thus seem to be inapplicable to real-world situations. These perceived natures of mathematics might have helped the participants to formulate negative images of mathematics during their academic journey. Furthermore, it signified that our mathematics curriculum, textbooks, and classroom teaching-learning practices rarely appreciate the inclusive and empowering images of mathematics as imperfect (Maheux, 2016), im/pure (Luitel, 2013), emerging human activities, contextual, and largely value-laden which in turn lead the practitioners towards a vicious circle of negativity.

The results of the study signified that most of the images held by the undergraduate students are negative that had largely emerged through the pedagogical practices and decontextualized curriculum and textbooks. Undergraduate students would be the teachers, teacher educators and curriculum designer, and their negative images of mathematics might be transmitted to their students and would be reflected in their future mathematical activities. Many studies showed that mathematical anxiety, attitude, beliefs, and perceptions of teachers supply the strong foundation for germinating different beliefs, attitudes, and perceptions of their students (Balbase, 2013; Jackson, 2008; Vinsion, 2001). If we do not address these forces of negative images of mathematics among undergraduate students, it may create a vicious circle of negative images, avoidance of mathematics, poor performance, and low self-confidence.

To bring a positive transformation, images of mathematics held by practitioners should be a concern for bringing desirable changes. In this connection, we argue that teacher education and teacher training programs should take into account the development of favourable images of mathematics in future teachers, educators, and policy makers at large so that they can explore and exploit the multidimensional nature of mathematics for the betterment of their personal and professional lives and mathematics education practices as well.

Moreover, Lane, Stynes, and O'Donghue (2014) claim that images of mathematics have a positive relation with mathematics teaching-learning activities. In this context, we claim that this study helps the students, teachers, mathematics educators, researchers, curriculum designers to critically re-examine their mathematical practices through the self-reflective practices that might open a new avenue of the transformative mathematics education practices. Finally, the most important implications of this research are that it explores the new discourse in mathematics education in a Nepalese context in which mathematics classrooms largely are the places in which students compelled to maintain 'status quo' and accept the 'taken for granted knowledge' as the form of universal and scientific knowledge. It works as the hidden factors of symbolic violence leading to pessimistic views about the mathematics and thus leading to inappropriate mathematics education within the classroom.

IJEME, Vol. 1, No. 2, September 2017, 147-168 


\section{CONCLUSION}

In the end, the findings of the study showed that the images of mathematics among the under graduate students are unique, personal and vary according to their experiences during their academic and professional journey. Besides their personal and unique experiences, their views converge on one or more in the four recurring themes. These themes include- mathematics as a difficult and abstract, decontextualized, mysterious and applicable body of knowledge. Most of these images hold by the participants emerged through one or more reasons such as mathematics education did not incorporate local cosmological knowledge and context, its symbolic structures, sacred and disempowering pedagogical practices, mathematical resources and materials are quite different from local cultural practices, only Nepali [or English] language of instruction and nature of mathematics itself. The selected theoretical lens of symbolic violence was found relevant to explore the images of mathematics because most of the images formed by the participants were enforced by within and outside school environment in which they urged to follow certain rules and formulations mostly unfamiliar and do not recognize their voices. These descriptions reveal that the images of mathematics are mostly negative and broadly emerged through conventional pedagogical and curricular practices. This note is a call for mathematics education community in Nepal and elsewhere to think about humanistic, contextual, constructive, and emergent mathematics in schools and higher education.

\section{REFERENCES}

Awasthi, L.D. (2004). Exploring the monolingual school practices in multilingual Nepal. Unpublished Doctoral Dissertation, Danish University of Education, Copenhagen, Denmark.

Belbase, S. (2006). My journey of learning and teaching mathematics from traditionalism to constructivism: A portrayal of pedagogical metamorphosis. M.Phil. Dissertation, Kathmandu University, Nepal.

Belbase, S. (2013). Image, anxieties, and attitudes toward mathematics. International Journal of Education in Mathematics, Science and Technology, 1(4), 230-237.

Belbase, S. (2015). Preservice secondary mathematics teachers' beliefs about teaching geometric transformations using Geometer's Sketchpad. PhD Dissertation, University of Wyoming, Laramie, Wyoming, USA.

Belbase, S. (2016). Reflective and reflexive beliefs of two pre-service secondary mathematics teachers. European Journal of Educational and Social Sciences, 1(1), 34-65.

Belbase, S. (2017). Attitudinal and cognitive beliefs of two pre-service secondary mathematics teachers. International Journal of Research in Education and Science (IJRES), 3(2), 307-326.

Beswick, K. (2007). Teachers' beliefs that matter in secondary mathematics classrooms. Educational Studies in Mathematics, 65, 95-120.

Bourdieu, P. \& Passeron, J.C. (1990). Reproduction in education, society and culture. (Nice, R. Trans.). London: Sage Publication.

Bourdieu, P. (1991). Language and symbolic power. (Raymond, G. \& Adamson, M. Trans.). UK: Polity Press. 
Bourdieu, P. (1995). Outline of a theory of practice. (Nice, R. Trans.). Cambridge: University Press.

Cohen, L., Manion, L., \& Morrison, K. (2007). Research methods in education (6 $6^{\text {th }}$ ed.). USA and Canada: Routledge.

Creswell, J.W. (2007). Qualitative inquiry and research design: Choosing among five approaches ( $2^{\text {nd }} \mathrm{ed}$.). New Delhi: Sage Publications.

Creswell, J.W. (2012). Educational research: Planning, conducting and 'evaluating quantitative and qualitative Research ( $4^{\text {th }}$ ed.). Boston: Pearson.

Ernest, P. (1991). The philosophy of mathematics education. UK: Routledge Falmer.

Ernest, P. (1994). The dialogical nature of mathematics. In Ernest, P. (Ed.). Mathematics education and philosophy: An international perspective. UK: The Falmer Press.

Ernest, P. (1998). Social constructivism as a philosophy of mathematics. USA: State University of New York Press.

Ernest, P. (2008). Epistemology plus values equals classroom image of mathematics. Philosophy of Mathematics Education Journal, 23, 1-12.

Ernest, P. (2012). What is our first philosophy in mathematics education? For the Learning of Mathematics, 32(3), 8-14.

FitzSimons, G.E. (2002). What counts as mathematics? Technologies of power in adult and vocational education. Netherlands: Springer.

Freire, P. (1973). Education for critical consciousness. New York: Continuum.

Giroux, H. (1992). Border crossings: Cultural workers and politics of education. New York: Routledge.

Goodwin et al. (2014). Exploring the relationship between teachers' images of mathematics and their mathematics history knowledge. Philosophy of Mathematics Education Journal, 28.

Grenfeel, M., \& James, D. (1998). Bourdieu and education: Acts of practical theory. UK: Falmer Press.

Hersh, R. (1997). What is mathematics really? New York: Oxford University Press.

Howse, M. (2006). What is the nature of African American teachers' beliefs about mathematics and how do this' belief relate to their beliefs about African American mathematics students? Unpublished Doctoral Dissertation, College of Education, the Florida State University, USA.

Jackson, E. (2008). Mathematics anxiety in students' teacher. Practitioner Research in Higher Education, 2(1), 36-42.

Kathmandu University and UNESCO Office in Kathmandu. (2008). Developing culturally contextualized mathematics resource materials: Capturing local practices of Tamang and Gopali communities. Lalitpur, Nepal: UNESCO Office in Kathmandu.

Kloosterman, P. (2003). Beliefs about mathematics and mathematics learning in the secondary school: Measurement and implication for motivation. In G. C. Leder, E. Pehkonen, \& G. Törner, (Eds.). Beliefs: A hidden variable in mathematics education? Dordrecht, The Netherlands: Kluwer Academic Publishers.

IJEME, Vol. 1, No. 2, September 2017, 147-168 
Lamichhane, B.R. (2016). Teachers' beliefs about nature of mathematics and pedagogical practices. A paper presented in First International Conferences on Transformative Education Research and Sustainable Development. Kathmandu University, Dhulikhel, Nepal.

Lamichhane, B.R. (2017). Recent trends of early grade mathematics curricula. A paper presented at the National Conferences on History and Recent Trends of Mathematics. Kathmandu, Nepal.

Lane, C., Stynes. M., \& O'Donghue, J. (2014). The image of mathematics held by Irish post-primary students. International Journal of Mathematics Education in science and Technology, 45(6), 879-891.

Lerman, S. (1990). Alternative perspectives of the nature of mathematics and their Influence on teaching of mathematics. British Educational Research Journal, 16(1), 53-61.

Luitel, B.C. \& Taylor, P.C. (2005). Overcoming culturally dislocated curriculum in a transitional society: an autoethnographic journey towards pragmatic wisdom. Paper presented at the annual meeting of the American Educational Research Association (AERA), SIG: Self-Study of Teacher Education Practices, Montreal.

Luitel, B.C. \& Taylor, P.C. (2007). The shanai, the pseudosphere and other imaginings: envisioning culturally contextualised mathematics education. Cultural Study of Science Education, 2, 621-655. Springer Science + Business Media B.V.

Luitel, B.C. (2009) Culture, worldview and transformative philosophy of mathematics education in Nepal: A cultural-philosophical inquiry. Unpublished Doctoral Dissertation, Curtin University of Technology.

Luitel, B.C. (2013). Mathematics as an im/pure knowledge system: symbiosis, (w)holism and synergy in mathematics education. International Journal of Science and Mathematics Education, 10(6).

Maheux, J.F. (2016). Wabi-Sabi mathematics. Journal of Humanistic Mathematics, 6(1), 174-195.

Mann, E.L. (2005). Mathematical creativity and school mathematics: Indicators of mathematical creativity in middle school students. Unpublished Doctoral Dissertation, University of Connecticut, Connecticut, United States.

Marshman, M. \& Grootenboer, P. (2012). Scissors, papers rock: Old-world technologies for future-proofing pedagogy. Re-engaging students in mathematics classrooms. In L. Rowan and C. Bigum (Eds.), Transformative approaches to new technologies and student diversity in futures oriented classrooms: Future proofing education. Australia: Springer Science+Business Media B.V.

Martin, L., \& Gourley-Delaney, P. (2014). Students' images of mathematics. Instructional Science, 42(4), 595-614.

Mason, M. \& Evers, C.W. (2010). Comparative education: Philosophical issues and concepts. In Peterson, P., Baker, E. \& McGaw, B. (Eds.). International encyclopedia of education (3 ${ }^{\text {rd }}$ ed.) (vol. 6). UK: Elsevier Ltd.

Mason, M. (2010). Critical theory and pedagogy. In Peterson, P., Baker, E. and McGaw, B. (Eds). International encyclopedia of education ( $3^{\text {rd }}$ ed.) (vol. 6). UK: Elsevier Ltd. 
Mathema, K.B. \& Bista, M.B. (2006). Study on Student Performance in SLC (Main Report). Kathmandu, Nepal: Ministry of Education and Sport and Education Sector Advisory Team, Kathmandu.

Mura, R. (1995). Images of mathematics held by university teachers of mathematics education. Educational Studies in Mathematics, 28(4), 385-399.

Osman, R., Pa, N.A.N., \& Othman. (2010). Images of mathematics held by students of diploma in actuarial sciences. Procedia Social and Behavioural Sciences, 8(2010), 219-227.

Palmer, H. (2015). Primary school teachers' images of a mathematics teacher. In C. Bernack-Schuler et al. (Eds.), Views and beliefs in mathematics education (122130). New York, NY: Springer.

Palmer, H., \& Karlsson, L. (2017). Primary school students' images of problem solving in mathematics. In C. Andra, D. Brunetto, E. Levenson, \& P. Liljedahl (Eds.), Teaching and learning in maths classroom (pp. 27-36). Cham, Switzerland: Springer.

Panta, B. (2016). Pondering on my beliefs and practices on mathematics, pedagogy, curriculum and assessment. Unpublished M.Phil. Dissertation, Kathmandu University, Nepal.

Panthi, R.K., \& Belbase, S. (2017). Teaching and learning issues in mathematics in the context of Nepal. European Journal of Educational and Social Sciences (EJESS), 2(1), 1-27.

Parveva, T., Noorani, S., Ranguelov, S., Motiejunaite, A., \& Kerpanova, V. (2011). Mathematics education in Europe: Common challenges and national policies. Education, Audiovisual and Culture Executive Agency, European Commission.

Patton, M.Q. (2002). Qualitative research and evaluation methods (3 ${ }^{\text {rd }}$ ed.). Thousand Oaks: Sage Publication, Inc.

Pradeep, R. (2006). A study of mathematics anxiety amongst primary pre-service teacher enrolled in Dutch teacher training program. Unpublished Master's Dissertation. University Van Amsterdam. The Netherlands.

Preston, P.A. (1986). Math anxiety: Relationship with sex, college major, mathematics background, mathematics performance, mathematics avoidance, self-rating of mathematics ability and self-rating of mathematics anxiety as measured by the revised mathematics anxiety rating scale (RMARS). Doctoral Dissertation, University of Tennessee, Knoxville.

Probert, B.S. (1983). A multimodal group intervention strategy in mathematics anxiety/avoidance. Unpublished Doctoral Dissertation, Graduate Council, University of Florida.

Rolka, K., \& Roesken-Winter, B. (2015). Networking theories to understand beliefs and their crucial role in mathematics education. In B. Pepin, B. Roesken-Winter (Eds.), From beliefs to dynamic affect systems in mathematics education (pp. 7393). New York: Springer.

Sam, L.C. (1999). Public image of mathematics. Unpublished Doctoral Dissertation, University of Exeter, Exeter, Devon, South West England, United Kingdom.

IJEME, Vol. 1, No. 2, September 2017, 147-168 
Sterenberg, G. (2008). Investigating teachers' images of mathematics. Journal of Mathematics Teacher Education, 11(2), 89-105.

Taylor, P.C. (1996). Mythmaking and myth breaking in the mathematics classroom. Educational Studies in Mathematics, 31(1/2), 151-173.

Taylor, P.C., \& Williams, M.C. (1992). Discourse towards balanced rationality in the high school mathematics classroom: Ideas from Habermas' critical theory. A paper presented in the "sociological and anthropological perspectives" working subgroup of seventh international congress of mathematics education (ICME-7), 17-23 August, Quebec.

Tutak, F.A., Bondy, E., \& Adams, T. (2011). Critical pedagogy for critical mathematics education. International Journal of Mathematics Education in Science and Technology, 42(1), 65-74.

Vinsion, B.Mc. (2001). Comparison of pre-service teachers' mathematics anxiety before and after a method class emphasizing manipulative. Early Childhood Education Journal, 29(2), 89-94.

Wolcott, H.F. (1994). Transforming qualitative data: Description, analysis and interpretation. Thousand Oaks, CA: Sage. 
